\title{
LEARNERS' PERCEPTION ON ONLINE LEARNING IMPLEMENTATION DURING COVID-19 PANDEMIC
}

\author{
${ }^{1}$ Indry Widyasti Anwar \& ${ }^{\mathbf{2} J u s m i n ~ H J ~ W a h i d ~}$ \\ ${ }^{1}$ English Lecturer, FKIP, Khairun University, Indonesia \\ ${ }^{2}$ English Lecturer, Muhammadiyah University of North Maluku, Indonesia \\ Corresponding Author Email: j.hj.wahid2010@gmail.com
}

\section{Article Info \\ Article History \\ Received: March 2021 \\ Revised: April 2021 \\ Published: April 2021}

\section{Keywords}

Writing instructions;

ELT learning;

Communicative learning;

\begin{abstract}
The massive and fast spread of the COVID 19 around the world has changed the way education works. The learning delivery in Schools and universities has been switched from conventional classrooms to online mode. This study aims to identify the learner's perception regarding online learning implementation during the COVID-19 pandemic. Participating in the study were 68 students of the English Education Study Program. Data collection was done through a survey questionnaire consisting of both open-ended and close-ended questions, and continued by interview activities. Researchers presented the results using descriptive qualitative techniques. Results from this research showed that students have a positive attitude toward the online learning experience in general. The implementation of online learning during a pandemic is considered an effective and cheap way of accessing knowledge. However, most students showed frustration due to bad internet access, which affects their learning success. Students also felt the need for improvement in terms of interaction and engagement between students and teachers.
\end{abstract}

How to cite: Anwar, I.W., \& Wahid, J.H.J. (2021). Learners' perception on online learning implementation during covid-19 pandemic, JOLLT Journal of Languages and Language Teaching, 9(2), 126-138, DOI: https://doi.org/10.33394/jollt.v\%vi\%i.3576

\section{INTRODUCTION}

As soon as the World Health Organization (WHO) declared a pandemic situation in March 2020 due to COVID-19 virus spread, the world is forced to stop every activity which requires big gathering and meetings. The pandemic has changed daily human activities, including the education sector. Students can no longer be physically present in the classroom as the threat of the virus has become more dangerous each day. Working activities are switched from traditional ways to online mode. Universities are also switching their traditional education setting into online learning by using various online platforms such as google classroom, Microsoft team, Zoom, Youtube, WhatsApp, and others (Gacs \& Spasova, 2020; Haerazi et al., 2020). Although the concept of online learning have long been used in many countries, to some society in rural parts of the world, the use of the online system in learning is still quite new (Paesani, 2020). The pandemic has set quite a big shock, especially to new developing universities, particularly in the Eastern part of Indonesia, where internet connection problems are often found. Lecturers are required to design effective online learning activities which the students can conveniently access.

Online learning is a type of distant learning where students and teachers do not meet in a traditional classroom setting, and the internet becomes its main media (Stern, 2018; Jamil \& Hamre, 2018). It is a process of teaching delivery to provide access to learning despite geographic proximity, time, or other possible reasons (Blake, 2011; Tarone, 2015). In a pandemic situation, traditional learning can expose students and teachers to the risk of serious 
health issues. Therefore, carrying out online learning mode is the safest choice. Online learning comprised two main elements, learning, and technology, where learning is the cognitive process to achieve information and knowledge while technology acts as a medium to enable the learning process (Aparicio, Bação \& Oliveira, 2016). Online learning can be delivered synchronously and asynchronously. Synchronous mode is when all distant participants are present at a specific organized time using web conferencing or video conferencing technology. While the asynchronous mode is delivered in a more flexible way where participants have the choice to access course materials anytime on their own need through electronic mails, message board forums, video, and audio recordings, and others (Alan et al., 2012).

Online learning is a low cost and convenient for learners to access it anywhere and anytime. Through online activities, learners have the autonomy to learn at their needs and wants (Hurlbut, 2018). It also provides up-to-date information and can be integrated with other elements to reinforce learners' comprehension such as audio and video explanation, group chats and forum, discussion board and quizzes (Cantoni, Cellario \& Porta, 2004). Holmes and Gardner (2006) noted that e-learning offers a new experience for learners in learning by its variety of interactions with the education community and exposes learners to cultural diversity and globalization in education by eliminating time and space boundaries.

The rapid development in technology and information in education is closely related to 21 st-century skills. Teachers and educators are responsible for assisting students in achieving the required skills of the 21 st century. Thus, teachers must first improve the expected relevant skills in the area of technology, information, media, and literacy to help students achieve their ability and skills to pursue their future and competitive career (Suherdi, 2012). In the framework of Partnership for 21st Century Skill (P21), one of the four aspects of skills required for students to master in the 21 st century education is information, technology, and media skill.

Students are direct subjects experiencing the implementation of technology in distant learning, which makes it important to identify their perception regarding the process. Online learning supports students in learning individually and collaboratively by utilizing various kinds of online learning platforms and learning methods. Furthermore, online learning promotes independent learning and reduces dependencies of students toward teachers' assistance (Kumi-Yeboah, Dogbey, \& Yuan, 2017). Positive responses were found in Cakrawati (2017) where the majority of respondents in the research showed satisfaction regarding the effectiveness of online learning process. Despite the complaints due to slow internet connection, participants described that Edmodo or Quipper's use as a media of online English learning to be effective and helpful. Many studies have identified positive attitude toward the benefit and effectiveness of online learning compared to traditional learning (Alsaaty, Ella, Abrahams \& Alshameri, 2016; Brown, 2016; Pai, 2013). Students perceived an increased motivation toward online learning and that online learning helped them understand course materials easily (Saifuddin, 2018). A study among students with visual impairment identified positive responses in the use of various online learning applications. Students appreciate the opportunity to learn using digital platforms in understanding the course material which they found to be interesting (Hamid, 2020).

Although the rapid growth of technology on the implementation of online learning might sound familiar for educators, it might not be the case for learners. Depending on where the online learning takes place, students' learning style, and state of being, they might perceive different expectations and reactions toward certain kinds of learning mode. In online learning, students' perceptions, needs, and expectations are important for teachers to consider before designing and developing online course materials (Sahin \& Shelly, 2008). Hassan \& Atan (2012) revealed that 'learners' attitude critically influences the success of e-learning 
activity. When learners maintain positive attitudes during online learning, they tend to get involved better in learning process.

The level of satisfaction in online learning was found to be crucially determined by the amount and quality of interaction betwen teachers and learners (Fedynich, Bradley \& Bradley, 2015). The research revealed that students are mostly satisfied with the course materials' clarity and organization but perceived that there needs to be more variety in terms of instructional design. Some learners stated their frustration for not getting immediate response to the course's questions (Fletcher \& Bullock, 2015). Sari (2020) informs that the implementation of online learning during COVID-19 pandemic faces some obstacles such as slow internet connection, the enourmous amount of tasks students received, limited interaction between teachers and students, and limited materials received compared to offline teaching. The availability of internet connection in rural areas, limited teaching media accessibility, and technology compatibility in accessing course materials are identified as the main influencing factors. These in EFL context determine the efficacy of online learning (Nur Agung, Surtikanti, \& Op, 2020). Therefore, this study aims to identify the learner's perception regarding online learning implementation during the COVID-19 pandemic. This study was conducted at the English Education Study Program.

\section{RESEARCH METHOD \\ Research Design}

The core focus on this research is to look into language learners' perspectives on the implementation of online learning in EFL classrooms during the COVID-19 pandemic. This research used descriptive qualitative method which aimed to gain a rich and deeper analysis of respondents' perceptions. Questionnaires were used to collect respondents' perceptions regarding the implementation of online learning.

\section{Instruments}

The instrument for the data collection was well prepared. Related to the research problems, the researchers used a questionnaire test as an instrument. The test used must be appropriate in terms of the object, the dependable in the evidence provides, and applicable to the particular situation. The questionnaire consists of close ended and open-ended questions. Close-ended questions are presented in 5 points Likert scale, ranging from strongly disagree to strongly agree. Close-ended questionnaires are used to determine the percentage from each item measured that will later be interpreted descriptively. Open-ended questions were used to identify students' perceptions regarding effectiveness and obstacles during online learning process. The questionnaires discuss three major aspects; students' participation, instructional design and delivery, and teachers' role and involvement. The questionnaire items were adapted and revised from Fedynich, L., Bradley, K. S., \& Bradley, J., (2015).

\section{Data Analysis}

The data of this study are students' perception on online learning in EFL classroom done by English lecturers at English language study program during Covid-19 pandemic. The data are collected using questionnaire. The results of this are analyzed in the form of percentage. The data then are followed up in some interview activities. The data resulted are analyzed using qualitative ways. The data analysis covers data condensation steps, data display steps, and conclusion drawing or verification. It is in line with Creswell (2008) who argues that the primary form for representing and reporting findings in qualitative research is a narrative discussion. Narrative discussion is a written passage in qualitative study in which authors summarize, in detail, the findings from their data analysis. 


\section{RESEARCH FINDINGS AND DISCUSSION Research Findings}

After completing the survey, 14 items of the close-ended questionnaires were divided into three major categories such as instructional design and delivery, teachers' role and involvement, students' participation, and accessibility. Results below are presented into different themes.

\section{Intructional Design and Delivery}

Table 1 shows result of the questionnaire data collected from the participants regarding instructional design and delivery of materials in online learning.

Table 1

Instructional Design and Delivery

\begin{tabular}{|c|c|c|c|c|c|c|}
\hline Item & Question & $\begin{array}{l}\text { Strongly } \\
\text { Disagree }\end{array}$ & Disagree & Neutral & Agree & $\begin{array}{c}\text { Strongly } \\
\text { Agree }\end{array}$ \\
\hline 3 & $\begin{array}{l}\text { Online courses provide clear } \\
\text { instructions to ptomote students' } \\
\text { comprehension }\end{array}$ & $5,9 \%$ & $32,4 \%$ & $41,2 \%$ & $16,2 \%$ & $4,4 \%$ \\
\hline 5 & $\begin{array}{l}\text { Online learning utilizes a wide range } \\
\text { of learning sources to support } \\
\text { learning (link to websites, articles, } \\
\text { videos, etc.) }\end{array}$ & $4,4 \%$ & $5,9 \%$ & $19,1 \%$ & $39,7 \%$ & $30,9 \%$ \\
\hline 9 & $\begin{array}{l}\text { Online learning provide students with } \\
\text { activities to develop critical thinking }\end{array}$ & $9 \%$ & $20,9 \%$ & $38,8 \%$ & $19,4 \%$ & $11,9 \%$ \\
\hline 10 & $\begin{array}{l}\text { Online learning provides clear } \\
\text { instructions to task submission }\end{array}$ & $3 \%$ & $11,9 \%$ & $47,8 \%$ & $34,3 \%$ & $3 \%$ \\
\hline
\end{tabular}

Teachers' Role and Involvement

Table 2

Teachers' Role and Involvement

\begin{tabular}{llccccc}
\hline Item & \multicolumn{1}{c}{ Question } & $\begin{array}{c}\text { Strongly } \\
\text { Disagree }\end{array}$ & Disagree & Neutral & $\begin{array}{c}\text { Agree } \\
\text { Strongly } \\
\text { Agree }\end{array}$ \\
\hline 4 & $\begin{array}{l}\text { Online learning provides for teachers' } \\
\text { formative assesment and feedback }\end{array}$ & $2,9 \%$ & $27,9 \%$ & $42,6 \%$ & $23,5 \%$ & $2,9 \%$ \\
\hline 6 & $\begin{array}{l}\text { During online learning, students are } \\
\text { able to ask questions and receive } \\
\text { explanatory feedback from teachers }\end{array}$ & $8,8 \%$ & $13,2 \%$ & $29,4 \%$ & $41,2 \%$ & $7,4 \%$ \\
\hline 7 & $\begin{array}{l}\text { Online learning platform provides } \\
\text { clear contact information of } \\
\text { instructors or institution for students } \\
\text { who need support }\end{array}$ & $8,8 \%$ & $19,1 \%$ & $39,7 \%$ & $29,4 \%$ & $2,9 \%$ \\
\hline 8 & $\begin{array}{l}\text { During online learning, students and } \\
\text { teachers interact and communicate } \\
\text { effectively }\end{array}$ & $13,4 \%$ & $29,9 \%$ & $40,3 \%$ & $13,4 \%$ & $3 \%$ \\
\hline
\end{tabular}

\section{Students' Participation}

The result from four questionnaire items that are categorized into the aspect of students' participation can be classified as follows:

Table 3

Students' Participation

\begin{tabular}{|c|c|c|c|c|c|c|}
\hline Item & Question & $\begin{array}{l}\text { Strongly } \\
\text { Disagree }\end{array}$ & Disagree & Neutral & Agree & $\begin{array}{c}\text { Strongly } \\
\text { Agree }\end{array}$ \\
\hline 1 & $\begin{array}{l}\text { Online learning promotes students' } \\
\text { motivation in learning }\end{array}$ & $14,7 \%$ & $35,3 \%$ & $33,8 \%$ & $14,7 \%$ & $1,5 \%$ \\
\hline
\end{tabular}




\begin{tabular}{|c|c|c|c|c|c|c|}
\hline 2 & $\begin{array}{l}\text { During online learning, students have } \\
\text { the opportunity to interact with each } \\
\text { other }\end{array}$ & $13,2 \%$ & $35,3 \%$ & $30,9 \%$ & $13,2 \%$ & $7,4 \%$ \\
\hline 11 & $\begin{array}{l}\text { Online learning promotes students' } \\
\text { active engagement in group tasks and } \\
\text { discussions }\end{array}$ & $8.8 \%$ & $30,9 \%$ & $32,4 \%$ & $25 \%$ & $2,9 \%$ \\
\hline 12 & $\begin{array}{l}\text { Online learning courses delivery are } \\
\text { interesting and engaging }\end{array}$ & $5,9 \%$ & $29,4 \%$ & $45,6 \%$ & $13,2 \%$ & $5,9 \%$ \\
\hline 13 & $\begin{array}{l}\text { Online learning promotes } \\
\text { autonomous learning environment }\end{array}$ & $5,9 \%$ & $11,8 \%$ & $55,9 \%$ & $17,6 \%$ & $8,8 \%$ \\
\hline
\end{tabular}

\section{Accessibility}

Open ended question results inferred that generally students are satisfied with the implementation of online learning during pandemic because it is a way to protect everyone from COVID-19 virus. Accessibility to course material is satisfactory, students are provided with clear instructions to access materials or to submit assignments. Teachers put extra effort in providing sufficient materials to support students comprehension by adding more details in printed materials, making audio or video explanation and doing video conference with all students.

\section{DISCUSSION}

Using technology to convey education's purpose is not a new thing. Universities need to reflect from this pandemic and started to invest in its human resources and technologies. Online learning can be made fun and effective only if every elements in distant learning are maximized. Findings from this study indicated a positive attitude toward online learning in general due to its practicallity and felxibility. Students through open-ended question mostly showed satisfaction regarding material delivery and instructional delivery. Feedback and formative assesment are adequately given thorughout the course by utilizing features of online learning such as video conferencing, discussion board, chat forum, and electronic mails.

This study see some aspects in online learning carried out by EFL lecturers in English language education study program such as parts of instructional design and delivery, teachers' roles and involvement, students' participation, and accessibility. The elaboration of these part can be presented one by one according with the research findings.

\section{Instructional design and delivery}

Most of the students have 'a neutral perception of whether online courses are presented with clear instructions that can support students' comprehension while 32,4\% disagree. Through open-ended question, students mentioned that learning online does not always work well. Students perceive that there is always lack of explanation and instruction from instructors which create confusion during learning. Students are given lots of assignments and independent reading tasks with minimum explanation which resulting in low level of comprehension. It is in line with Gao et al. (2016) who inform that online learning gives chances for teachers to provide many kinds of learning tasks. It can create bad atmosphere for students and also fell bored with the tasks. In this study, some students also mentioned that sometimes students could misunderstand the information given by instructors because of limited interaction.

"While studying online I easily access material from the internet and a problem I often encounter in studying online is lack of understanding in the delivery of material".

"I hope the pandemic will end soon so that online learning will also end. Online learning very ineffective because learning is also not well conveyed".

"My opinion online learning during pandemic is not effective because sometimes we don't understand what the teachers said". 
Jonassen et al. (2019) proposed the construct of instructional strategies which are distinguished from learning strategies. Instructional strategies are seen as enablers to learning where teachers do planning and prepare techniques in order to engage learners in learning process. Without sufficient instructional strategies, learning process can not run well.

On the other hand, positive responses were found for item 5 where $39,7 \%$ students agree and 30,9\% strongly agree that through learning online, students can access a wide range of learning sources such as websites, articles, videos, and audios. The students mentioned that online learning benefits are they have unlimited access to relevant learning materials from websites, academic articles, blogs, Youtube, and audio recording. Students are gradually developing their skill of utilizing technology and searching for information on the internet through online learning.

"Unlike face-to-face learning, online learning have some proble like connection. But on the plus side, I think it is a good step because with online learning I realized that education are developing in this digital era"

$20,9 \%$ of students disagree that online learning activities enhance students' critical thinking. On the other hand, with only a bit different in numbers, 19,4\% of students actually agree that critical thinking ability can be improved through learning online. This might be due to the abscence of direct interaction between students and teachers as facilitators. In order to construct critical thinking ability, teachers need to plan stimulating activities to support students' coprehension. In online learning, many obstacles are found such as weak internet connection and shortage of internet bundles might cause students to focus less. Meanwhile, some students mentioned that teachers often only delivered little explanation during the course or provided them with independent reading tasks followed by assigments. Learners have different preference in terms of learning style. Some learners might prefer direct and guided explanation in order to adapt with the new learning environment. This is in line with previous research by $\mathrm{Oh} \& \operatorname{Lim}$ (2005) who underlined that often times in online platform, learning is not directly guided and students are expected to self-direct in autonomous learning.

"The challenge is of course the bad internet network and there is also a lecturer who never explains the material at all and only give a lot of assignment."

"...it is even more difficult when the question / assignments given are not giver prior explanation or clear grids."

During online learning, students are required to submit assignment and projects online. Students mostly agree that teachers gave clear instruction about submitting tasks $(34,3 \%)$ while $47,8 \%$ of them are neutral. Students mentioned that they were not worried about submitting task because they are quite familiar in using electronic mails and other online learning platforms. However, students complained about not having enough internet credit to access materials and submit assignments. University is providing them internet credit thoughout online learning but it is not enough because they have many courses in a week. $79,4 \%$ students still rely on their cellphones to access online learning. The amount of materials and assignments that they have to download everyday are making their cellphones down due to extreme capacity.

"Even though the online system makes it easier for a lot of work, in the learning process, we get additional work, namely creating and sending photos, videos, downloading materials, and uploading tasks have been done. All of that requires a long time in the process. My cellphone's memory is full."

"In my opinion, online learning is not very effective because there are many challenges, such as when the network is zooing so that we cannot clearly hear the material being conveyed, then the internet quota runs out". 


\section{Teachers' roles and involvement}

$27,9 \%$ perceive that formative assesment and feedback are not effectively given in online learning mode. Meanwhile, 23,5\% participants actually agree that teachers' provide sufficient assesment and feedback during online learning. Author assumes that this might be due to variety of teachers' style in teaching. Some teachers are very attentive and would take the effort to provide learners with feedback that they need. In an offline setting, it is much easier for teachers to provide immediate assesment and feedback on students' performances. Activities in classroom are directly monitored and teachers have the opportunity to engage with students. However in learning online, interaction is very limited which might cause teachers to focus more on explaining materials and put less time in providing formative assesment.

"In my opinion, online learning does not really help students in understanding the material they receive, why do I say that, because there is no feedback between students and lecturers, then the network disruptions and so on."

$41,2 \%$ participants mostly showed satisfaction in terms of getting teachers' explanatory feedback when students are giving questions during online learning. Although students mostly complained about weak internet connection that often disturb learning process, students are still able to ask questions and receive answers from teachers. Many features in online learning platform that allow teachers and students to engage in direct interaction such as video conference, chat room or discussion board.

$39,7 \%$ participants were on neutral agreement when asked whether online learning platform provides them with clear contact information of instructors or institution. Providing contact information is important so that students who need technical help can reach out and get suppor they need. 29,4\% of students agree that they are given clear information on who to contact when support is needed. During online learning, students and teachers use various online applications to stay in contact such as WhatsApp, google classroom, electronic mail, Zoom , Google Meet and others. The applications are generally easy to operate and beneficial to use in learning online. Besides, the university has developped a website based online learning platform for teachers and students to use calles Virtual Classroom. Upon registering, students can see all contact of lectures from the website.

Among sixty-eight participants, 29,9\% of them are against the statement that students and teachers interact effectively during online learning. 40,3\% are on neutral agreement about the following statement. Interaction is an important determiner of online learning experience success. Through open ended question from the questionnaire, weak internet connection is one of the factor that causes ineffectivity of communication during learning process. Students perceive that it is less effective to communicate with teachers during online learning which cause reduced motivation and comprehension.

"I have several reasons why this type of method (online learning) doesn't really good for student while the pandemic. Firstly it lack of communication between students and teacher. Secondly there are some places which is have a bad connection as it impacted on our study and our score on that study."

"The benefit of online learning is that it can help students express their thinking skill and helping students to understand more about how to use online media in learning. The challenge in learning online lies in the lack of a good internet network and there is no direct communication between students and teachers".

Previous studies pointed out that communications between teachers and learners (FrajHussein et al., 2012; Sela, 2005; Tudor et al. 2015) and between learners with other learners (Fedynich, Bradley, \& Bradley, 2015) are part of essential elements that influence students' attitude toward online learning. The positive dynamics of online learning is crucially influenced by social communication among teachers and learners and a supporting learning 
environment that boosts students' self confidence (Tudor et al., 2015). Apparently, students felt the lack of nonverbal act such as gestures, facial expression, and body language.

\section{Students' participation}

Students perceive that online learning demotivates their motivation in learning. From the questionnaire result it can be obtained that $35,3 \%$ disagree and $14,7 \%$ strongly disagree. This data is also supported with students' description through open ended questions that although learning online is beneficial in terms of time and location, they can hardly concentrate throughout the course.

"In my opinion, online learning have some benefits like we can join the class online wherever we are or what we do, and keep enjoy it. Have more flexible time. But the challenges while learning online is we so fast be boring."

"Online learning during the pandemic has several benefits like I can do other activities. However, there are many challenges that must be faced, starting from the lack of explanation, lack of interaction, decreased learning motivation, and inapropriate course hours."

This result is in line with Fedynich, Bradley \& Bradley (2015) where majority of students in the survey perceived that it takes high level of self motivation to be successful in online course. Without persistence self motivation, students will be demotivated in learning and reduce their participation in classroom learning.

Another disagreement were found regarding lack of interaction between students during online learning. 35,3\% disagree and 13,2\% strongly disagree that online learning provides the opportunity for students to interact with each other. Rojabi (2020) found the same response where students in the survey described that the possibility of misunderstanding between students during online learning is high due to the limited interaction and low connection to internet. The challenge particularly occured when students are given group project and have to work online. The unstable internet connection and lack of direct interaction can create possible misunderstanding.

"The challenge in learning online lies in the lack of a good internet network and there is no direct communication between students and teachers"

$30,9 \%$ students showed disagremeent that online learning promotes active engagement between students in group tasks and discussion. Students perceive that doing group tasks is difficult because they can not gather in the same place. Discussion needs to be carried out online through group chats, video conference or discussion boards. Lack of interaction and limited coordination among students followed with bad internet connection causes reduced engagement. Moreover, students are less active during online group presentation and discussion. This is due to the lack of face-to-face interaction like in an offline classroom setting. The same situation was also found in Atmojo \& Nugroho (2020) where students identified the need for physical presence that can support their emotional bond between students and teachers. It was found that students are less motivated during online discussion and learning. The absence of physical presence causes the to feel lazy and less focus during learning thus, the online learning is not optimized.

Students also perceived that online learning is not quite interesting and engaging showed by questionnaire result where $29,4 \%$ disagree and $45,6 \%$ are neutral. The change of learningcircustances in students life might cause them to lose interest in learning online. Some students mentioned the need of interacting directly with their friends and teachers as a social human being. Direct eye contact, physical interaction and social support in a traditional classroom setting are some important factors that infuencing students' engagement. Not being able to experience the dynamic of authentic classroom experience influence students' motivation. Some students mentioned that they felt unmotivated and lazy to study from home everyday. 
Online learning provides opportunity for students to practice independent learning. $55,9 \%$ students have neutral agreement whether online learning promotes autonomous learning while $17,6 \%$ agree. Students during online learning use the opportunity of engaging technology and their learning needs independently. Depending on their learning style preference and psychological factors, learners may reach autonomy in learning online.

"The benefits of learning online include learning to be done anywhere and anytime, learning can also be adjusted to the capacity of each student. Online learning also ephasizes student initiative and independence."

However from the questionnaire result it can be viewed that students are not certain about achieving autonomous state of learning. Zhong (2018) inferred that student autonomy is very dynamic and depends heavily on environmental factors such as teachers' guidance and learning situation. Learning in isolation can gradually build learning autonomy through teachers' guidance and support while learning collaboratively with other students.

\section{Accessibility}

Moreover, online learning is considered practicial and beneficial for its flexibility in terms of time. Students admitted that they do not need to dress neatly for college, they save more money they used to pay for transport fees and that online learning can be done anywhere. However, students are facing problems of internet availability because not every places in their region can support them with good internet access. For some other students, internet data bundles are not affordable and not enough to access abundant of materials from teachers. Students mentioned that they often had to purchase internet data multiple times in a month which is quite costly. Despite the flexibility, the cost of online learning is highly determined from the availability of the internet data purchase.

"This means there is no need to go back and forth from one place to another. In addition, you not only save time, but you also save money, which can be spent on other priorities. However, there are also obstacles during learning online, namely slow internet network, expensive quota prices, difficult to interactive, etc."

"Online learning during this pandemic certainly has its benefits and challenges such as being at home we can spend time with family and ourselves. And the challenges are such as internet data that must be purchased every month which is quite a burden for parents who have middle to lower economies."

Challenge of learning online are not only found in internet connection. 79,4\% participants used their mobile phones throughout online learning. Students are required to download abundant of learning materials everyday from each different subjects such as PDF or word document materials, lecture audio, videos and handouts. Meanwhile after each learning activity, students are often asked to submit assignments as well. All these activities using mobile phones require the utilization of various mobile phone applications. Some students reported that their phones are going slow or not working due to excessive data memory used. Laptops are only owned by some students because not all students can afford them. This phenomena puts some students in disadvantage because they can not experience learning as it should.

"Even though the online system makes it easier for a lot of work, in the learning process, we get additional work, namely creating and sending photos, videos, downloading materials, and uploading tasks that have been done. All of that requires a long time in the process. My cellphone's memory is full"

Findings from the survey indicated that generally students felt the lack of interaction and engagement during online learning process. When learning online, teachers need to ensure that course materials are dilevered succesfully while having students engaged with the process of learning. Kearsley (2000) stated that teachers carry the role to ensure students are engaged in a high degree of participation and interaction. But often in the online learning environment, students felt greater isolation between other learners, reduced motivation and 
satisfaction, and poor academic performance due to teachers' failure to understand the dynamics of of online learning environment. Therefore, teachers need to encourage a greater classroom interaction by refocusing their teaching strategy throughout the course. At the beginning of the course, teachers might deliver a big portion of class input and lead by example. However, as the term goes by, teachers need to consider switching role from being a core "provider" to be a "facilitator" and produce lesser classroom input. This strategy should be followed by fostering a friendly classroom discussion, giving immediate feedback, and encouraging more active participation from the students.

Through the findings of this study, it can be inferred that internet availability and accessibility hold a crucial role to ensure the success of online learning. Students reported difficulties in communicating with other members of the class due to bad internet connection. Thus, researchers provide some implications for further online teaching process for universities to consider. Students should be supported with technical aspects of online learning as clearly as possible. Instructors along with institution should prepare for supplementary plan whenever students report challenges or problems during learning. Students should also be provided with free internet data bundles to ensure all students get the same opportunity to access course materials. Lastly, instructors should gradually evaluating their teaching strategy in order to develop an effective online learning environment.

\section{CONCLUSSION}

The present study discovered learners' perception of learning using the online media during COVID 19 pandemic. Findings indicated general satisfactory among learners regarding instructional design and delivery of online learning including the provision of materials, supporting learning materials and instructions to tasks submission. Students felt the need for improvement in designing activities to engage their critical thinking. To create a meaningful classroom interaction, teachers must ensure all students get the opportunities to ask questions and receive immediate feedback.

Formative assessment must also be provided timely through each courses. Teachers along with policy makers of the institution have to reshape the dynamic of online learning delivery in order to create greater participation and engagement between students, not only in independent tasks but also tasks that involve group work. Online learning delivery can be made interesting to boost students' motivation during their effort of learning autonomously from home. Lastly, accessibility to internet connection as the main medium to online learning holds important to bridge students and teachers in learning. In the least developped region, low internet connection heavily affecting online learning process. Therefore, university need to provide students with support to get access to internet through subsidized internet data.

\section{ACKNOWLEDGEMENT}

This thesis would not be finished without any help from the others. Therefore, the researcher would like to give his appreciation and thanks to all colleagues who have support and giving comments in any part of this article. Criticisms or suggestions from the readers very much expected to perfection this article. Furthermore, researchers hope this article can help readers to add scientific specialties. 


\section{REFERENCES}

Agung, A S N. (2019). Current Challenges in Teaching English in Least-developed Region in Indonesia. Jurnal Sosial dan Humaniora. [Journal of Social Sciences and Humanities], Volume 9(3), 266-271.

Alam, Zainab \& Waqar, Aqil \& Zaman, Khalid \& Shehzadi, Beenish \& Mehmood, Yasir. (2012). Perception of Students towards Distance Learning: A Case Study of Pakistan. Journal of American Science. http://www.jofamericanscience.org/journals. 509-517.

Alsaaty, Falih \& Carter, Ella \& Abrahams, David \& Alshameri, Faleh. (2016). Traditional Versus Online Learning in Institutions of Higher Education: Minority Business Students' Perceptions. Business and Management Research. 5. 10.5430/bmr.v5n2p31.

Aparicio, Manuela \& Bação, Fernando \& Oliveira, Tiago. (2016). An e-Learning Theoretical Framework. Journal of Educational Technology Systems. 19. 292-307.

Atmojo, Arief \& Nugroho, Arif. (2020). EFL Classes Must Go Online! Teaching Activities and Challenges during COVID-19 Pandemic in Indonesia. Register Journal. 13. 49-76. 10.18326/rgt.v13i1.49-76.

Blake, R. J. (2011). Current trends in online language learning. Annual Review of Applied Linguistics, 31, 19-35. https://doi.org/10.1017/S026719051100002X

Brown, J. C., \& Park, H. S. (2016). Longitudinal student research competency: Comparing online and traditional face-to-face learning platforms. Advances in Social Work, 17(1), 44-58. http://dx.doi.org/10.18060/20870

Cakrawati, L. M. (2017). Students' Perceptions on the Use of Online Learning Platforms in EFL Classroom. English Language Teaching and Technology Journal, 1(1), 22-30.

Cantoni, V., Cellario,M., and Porta,M.(2004). Perspectives and Challenges in E-learning: Towards Natural Interaction Paradigms. Journal of Visual Languages and Computing, $15,333-345$.

Creswell, John W. (2008). Educational Research Planning, Conducting, and Evaluating Quantitative and Qualitative research.Pearson Prentice Hall

Fedynich, L., Bradley, K. S., \& Bradley, J., (2015). Graduate students' perceptions of online learning. Research in Higher Education Journal, 27(1), pp. 1-13.

Fraj-Hussein, R., Barak, M., \& Dori, Y. (2012). Lifelong learning at the Technion: Perceptions of distance learning and learning experiences of students. (Doctoral dissertation). Faculty of Education for Science and Technology: Haifa, Israel.

Gacs, A., \& Spasova, S. (2020). Planned online language education versus crisis - prompted online language teaching: Lessons for the future. Foreign Language Annals, 53(2), 113. https://doi.org/https://doi.org/10.1111/flan.12460

Gao, X., Samuel, M., \& Asmawi, A. (2016). Online Features of Qzone Weblog for Critical Peer Feedback to Facilitate Business English Writing. Journal of Educational Technology Systems, 45(2), 285-301. https://doi.org/10.1177/0047239516659865

Haerazi, H., Utama, I. M. P., \& Hidayatullah, H. (2020). Mobile Applications to Improve English Writing Skills Viewed from Critical Thinking Ability for Pre-Service Teachers. International Journal of Interactive Mobile Technologies (IJIM), 14(07), 58. https://doi.org/10.3991/ijim.v14i07.11900

Hamid, Sitti. (2020). Online Digital Platforms During Covid-19 in EFLClasses: Visual Impairment Student' Perception. Eternal (English, Teaching, Learning, and Research Journal). 6. 328. 10.24252/Eternal.V62.2020.A10.

Hassan, Hasmawati \& Atan, Hanafi. (2012). Student Engagement in Online Learning: Learners Attitude Toward E-Mentoring. Procedia - Social and Behavioral Sciences. 67. 464-475. 10.1016/j.sbspro.2012.11.351. 
HJ, Wahid, Jusmin\& Thais, A, Iswan.(2020). Chunking Strategy; In Enhancing Fourth Semester Students' Reading Skill at English Department of Muhammadiyah University. Jo-ELT FakultasPendidikandanBahasa Program StudiPendidikanBahasaInggris IKIP.

Holmes, B. \& Gardner, J. (2006). E-Learning: Concepts and Practice. London: SAGE Publications.

Hurlbut, A. R. (2018). Online vs. traditional learning in teacher education: a comparison of student progress. American Journal of Distance Education, 32(4), 248-266. https://doi.org/10.1080/08923647.2018.1509265

Jamil, F. M., \& Hamre, B. K. (2018). Teacher Reflection in the Context of an Online Professional Development Course: Applying Principles of Cognitive Science to Promote Teacher Learning. Action in Teacher Education, 40(2), 220-236. https://doi.org/10.1080/01626620.2018.1424051

Jonassen, D. H., Grabinger, R. S., \& Harris, N. D. C. (2019). Analyzing and Selecting Instructional Strategies and Tactics. Originally published in 1991, PIQ 4.2. Performance Improvement Quarterly, 10(1), 34-54. doi:10.1111/j.19378327.1997.tb00029.x

Kearsley, G. (2000). Online Education: Learning and Teaching in Cyberspace. Belmont, CA.: Wadsworth/Thomson Learning.

Kumi-Yeboah, A., Dogbey, J., \& Yuan, G. (2017). Online Collaborative Learning Activities: The Perceptions of Culturally Diverse Graduate Students. Online Learning, 21(4), 5-28. doi: $10.24059 /$ olj.v21i4.1277

Ncube, L., (2015). Students' Perceptions of E-Learning in the Department of Information Science at the University of South Africa. UNISA.

Nur Agung, A.S.S, Surtikanti, M.W, \& OP,C.A.Q. (2020). Students' Perception of Online Learning During COVID-19 Pandemic: A Case Study on the English Students of STKIP Pamane Talino. Soshum: Jurnal Sosial Dan Humaniora, 10(2), 225-235. doi:10.31940/soshum.v10i2.1316

Oh, E. and Lim, D. (2005). Cross Relationships Between Cognitive Styles and Learner Variables in Online Learning Environment. Journal of Interactive Online Learning, 4 (1) 8

Paesani, K. (2020). Teacher Professional Development and Online Instruction : Cultivating Coherence and Sustainability. Foreign Language Annals, 53(2), 292-297. https://doi.org/10.1111/flan.12468

Pai, K. (2013). Assessing Online versus Face-to-Face Learning, Proceedings, Global Conference on Business \& Finance, 8(2), 350.

Roddy, C., et. al. (2017). Applying Best Practice Online learning, Teaching, and Support to Intensive Online Environments: an Integrative Review. Frontiers in Education, 2(November), 1-10. https://doi.org/10.3389/feduc.2017.00059

Rojabi, A. (2020). Exploring EFL Students' Perception of Online Learning via Microsoft Teams: University Level in Indonesia. English Language Teaching Educational Journal, 3(2), 163-173. doi:https://doi.org/10.12928/eltej.v3i2.2349

Sahin, I., \& Shelley, M. (2008). Considering Students' Perceptions: The Distance Education Student Satisfaction Model. Educational Technology \& Society, 11(3), 216-223.

Saifuddin, M. F. (2018). E-Learning dalam Persepsi Mahasiswa. Jurnal VARIDIKA, 29(2), 102-109. https://doi.org/10.23917/varidika.v29i2.5637

Sari Famularsih. (2020). Students' Experiences in Using Online Learning Applications Due to COVID-19 in English Classroom. Studies in Learning and Teaching, 1(2), 112-121. https://doi.org/10.46627/silet.v1i2.40 
Sela, A. (2005). Comparison of Face-to-Face Learning and Distance Learning in the Framework of Studies for Teaching Certificates. Israel: Oranim College, Mofet Institute, in Hebrew.

Suherdi, D. (2012). Towards the 21st Century English Teacher Education: An IndonesianPerspective. Celtic Press.

Stern, J. (2018). Introduction to Online Teaching and Learning. International Journal of Science Education, 3, 1-10. https://doi.org/10.1002/9781118784235.eeltv06b

Tarone, E. (2015). The issue: Online Foreign Language Education: What Are the Proficiency Outcomes?

Modern Language

Journal,

99(2),

392-393. https://doi.org/10.1111/modl.12220

Tudor, S., Stan, M., \& Paisi-Lazarescu, M. (2015). Integration of the e-Learning in Teaching /Learning Courses at Preschool and Primary Pedagogical Teacher. eLearning \& Software for Education, 2, 340-345.

Zhong, Q. M. (2018). The Evolution of Learner Autonomy in Online Environments: A Case Study in a New Zealand Context. Studies in Self-Access Learning Journal, 9(1), 7185. https://doi.org/10.37237/090106 